\title{
PENGARUH PEMBERIAN YOGHURT SINBIOTIK TANPA LEMAK DENGAN PENAMBAHAN TEPUNG GEMBILI (DIOSCOREA ESCULENTA) TERHADAP KADAR KOLESTEROL TOTAL TIKUS HIPERKOLESTEROLEMIA
}

\author{
Surya Saputra, Ani Margawati*) \\ Program Studi Ilmu Gizi Fakultas Kedokteran Universitas Diponegoro \\ Jl.Dr.Sutomo No.18, Semarang, Telp (024) 8453708, Email : gizifk@ undip.ac.id
}

\begin{abstract}
Background: Hypercholesterolemia is one of the risk factors for cardiovascular disease, which becomes one of the main causes of death in the world. Yoghurt is a fermented milk product, produced by lactic acid bacteria and has been proved to lower cholesterol. The addition of prebiotic, like inulin can support hypocholesterolemic effect in yoghurt. Lesser yam (Dioscorea esculenta) is high inulin food. This study aims to determine the effects of non-fat synbiotics yoghurt with addition of lesser yam flour to decrease total cholesterol level in hypercholesterolemic rats.

Method: True experimental study with pre-post test was conducted to 24 hypercholesterolemia-induced male Wistar rats which grouped using simple random sampling system into 1 control group and 3 treatment groups. Various amounts of non-fat synbiotics yoghurt with addition of lesser yam flour were administered, as much as $2 \mathrm{ml}, 3 \mathrm{ml}$, and $4 \mathrm{ml}$ for 14 days. Total cholesterol level were determined using CHOD-PAP methods.

Result: Total cholesterol decreased in P1's 11,28\% ( $p=0.077)$, P2's 12,16\% ( $p=0.102)$, and P3's 17,89\% ( $p=0.002)$. Conclusion: Administration of non-fat synbiotics yoghurt with addition of lesser yam flour $4 \mathrm{ml}$ day in two weeks significant $(p<0.05)$ reduce the total cholesterol on rats hyperkolesterolemic.

Key words: yoghurt, prebiotic, inulin, BAL, total cholesterol, hypercholesterolemia
\end{abstract}

\begin{abstract}
ABSTRAK
Latar belakang: Hiperkolesterolemia merupakan faktor risiko penyakit kardiovaskuler, yang menjadi penyebab utama kematian di dunia. Yoghurt merupakan susu yang difermentasi bakteri asam laktat (BAL) dan telah terbukti dapat menurunkan kolesterol. Penambahan prebiotik, seperti inulin dapat menunjang efek penurunan kolesterol pada yoghurt. Gembili (Dioscorea esculenta) merupakan bahan makanan tinggi inulin. Penelitian ini bertujuan mengetahui pengaruh pemberian yoghurt sinbiotik tanpa lemak dengan penambahan tepung gembili terhadap penurunan kolesterol total pada tikus hiperkolesterolemia.

Metode: Penelitian eksperimental murni dengan pre-post test yang diterapkan pada 24 tikus Wistar jantan terinduksi hiperkolesterolemia yang dikelompokkan menggunakan sistem acak sederhana menjadi 1 kelompok kontrol dan 3 kelompok intervensi. Subjek diberikan yoghurt sinbiotik tanpa lemak dengan penambahan tepung gembili sebanyak $2 \mathrm{ml}, 3 \mathrm{ml}$, dan $4 \mathrm{ml}$ selama 14 hari. Kadar kolesterol total ditentukan melalui metode CHOD-PAP.

Hasil: Kelompok P1 menunjukkan penurunan kadar kolesterol total 11,28\% ( $p=0.077)$, kelompok P2 mengalami penurunan kadarkolesterol total 12,16\% ( $p=0.102)$, dan kelompok P3 mengalami penurunan kolesterol total 17,89\% $(p=0.002)$.

Simpulan: Pemberian dosis yoghurt sinbiotik tanpa lemak dengan penambahan tepung gembili dengan dosis 4 ml/hari dalam waktu 2 minggu dapat menurunkan kadar kolesterol total darah tikus hiperkolesterolemia secara signifikan $(p<0.05)$.
\end{abstract}

Kata kunci: yoghurt, prebiotik, inulin, BAL, kolesterol total, hiperkolesterolemia

\section{PENDAHULUAN}

Penyakit kardiovaskuler merupakan penyebab kematian utama didunia. Prediksi World Health Organization (WHO) di tahun 2030, penyakit kardiovaskuler dapat menyebabkan kematian sekitar 23,3 juta manusia di dunia. ${ }^{1}$ Salah satu faktor risiko penyakit kardiovaskuler adalah hiperkolesterolemia. ${ }^{2}$ Berdasarkan Riset Kesehatan Dasar (RISKESDAS) tahun 2013, proporsi penduduk Indonesia $\geq 15$ tahun dengan kadar kolesterol total di atas nilai normal adalah sebesar $35,9 \% .^{3}$ Penurunan $1 \%$ kolesterol darah dapat mengurangi $2,3 \%$ risiko penyakit jantung koroner. ${ }^{4}$
Salah satu alternatif cara yang aman untuk menurunkan kadar kolesterol total darah adalah dengan modifikasi diet. ${ }^{5}$ Modifikasi diet yang dimaksud adalah konsumsi probiotik dan prebiotik yang lebih dikenal sebagai sinbiotik. ${ }^{6}$ Yoghurt sinbiotik tanpa lemak merupakan pangan fungisional berbahan susu skim/tanpa lemak yang difermentasi menggunakan bakteri asam laktat (BAL) Streptococcus thermophilus dan Lactobacillus bulgaricus sebagai probiotik serta penambahan inulin sebagai prebiotik. ${ }^{7,8}$ Prinsip penggunaan bakteri asam laktat sendiri, telah lama dipercaya sebagai cara alami untuk menurunkan

${ }^{*}$ Penulis Penanggungjawab 
kadar kolesterol total darah. ${ }^{9}$ Sumber inulin yang digunakan berasal dari umbi gembili (Dioscorea esculenta). Dibandingkan dengan semua jenis umbi, gembili memiliki kadar inulin tertinggi, dengan $14.77 \%$ berat keringnya. ${ }^{10}$ Penelitian pada manusia menunjukan penurunan kadar kolesterol total darah sehubungan dengan konsumsi inulin. ${ }^{6}$ Penelitian lain menunjukan pemberian diet sinbiotik berupa susu yang mengandung Lactobacillus acidhophilus dan $2,5 \%$ fruktooligosakarida sebanyak $375 \mathrm{ml}$ dapat menurunkan kadar kolesterol total, kolesterol LDL (Low Density Lipoprotein), dan ratio LDL/HDL (High Density Lipoprotein) sebesar $4,4 \%, 5,45$, dan $5,3 \% .^{6}$

Penelitian mengenai pemberian yoghurt sinbiotik tanpa lemak dengan penambahan tepung gembili terhadap kolesterol total belum pernah dilakukan. Berdasarkan uraian tersebut, penelitian ini dilakukan untuk mengetahui bagaimana pengaruh pemberian yoghurt sinbiotik tanpa lemak dengan penambahan tepung gembili terhadap penurunan kolesterol total pada tikus Wistar hiperkolesterolemia

\section{METODE}

Penelitian ini menggunakan rancangan true experiment dengan pre-post test randomized control group design. Variabel bebas adalah pemberian yoghurt sinbiotik tanpa lemak dengan penambahan tepung gembili, sedangkan variabel terikat adalah kadar kolesterol total tikus hiperkolesterolemia. Sampel penelitian dibagi menjadi 4 kelompok yaitu, kelompok kontrol (tidak diberikan yoghurt sinbiotik tanpa lemak dengan penambahan tepung gembili), kelompok perlakuan 1 (diberikan yoghurt sinbiotik tanpa lemak dengan penambahan tepung gembili sebanyak $2 \mathrm{ml}$ ), kelompok perlakuan 2 (diberikan yoghurt sinbiotik tanpa lemak dengan penambahan tepung gembili sebanyak $3 \mathrm{ml}$ ), kelompok perlakuan 3 (diberikan yoghurt sinbiotik tanpa lemak dengan penambahan tepung gembili sebanyak $4 \mathrm{ml}$ ).

Jumlah sampel penelitian menggunakan ketentuan WHO, dimana jumlah minimal subjek penelitian untuk tiap kelompok adalah sebanyak 5 ekor. ${ }^{11}$ Pada penelitian ini terdapat empat kelompok yaitu satu kelompok kontrol dan tiga kelompok perlakuan, sehingga jumlah sampel keseluruhan yang dibutuhkan sebanyak 20 ekor. Untuk mengantisipasi adanya drop-out maka jumlah sampel tiap kelompok ditambah menjadi 6 ekor, sehingga jumlah sampel keseluruhan yang dibutuhkan yaitu sebanyak 24 ekor.

Seluruh subjek penelitian dipelihara di kandang individual dan diberi pakan standar sebanyak 20 gram serta air minum ad libitum. Masing-masing subjek sudah dikelompokkan sebelum aklimatisasi. Di akhir tahapan aklimatisasi dilakukan pengambilan darah untuk mengetahui kadar kolesterol total awal. Sebelum pengambilan darah, semua subjek dipuasakan selama 12 jam. Selanjutnya subjek diberikan pakan tinggi kolesterol berupa otak sapi kukus yang dihaluskan dengan aquades menggunakan perbandingan 2:1 yang diberikan sebanyak $2 \mathrm{ml} /$ ekor/hari selama 14 hari melalui sonde. Pengambilan darah kedua dilakukan pada hari ke-22 untuk mengetahui kadar kolesterol total. Setelah itu, subjek diberikan yoghurt sinbiotik tanpa lemak dengan penambahan tepung gembili selama 14 hari melalui sonde. Yoghurt yang akan diberikan diencerkan dengan air agar bisa diberikan secara sonde. Di hari ke-37 dilakukan pengambilan darah akhir untuk mengetahui kadar kolesterol total post-intervensi. Pengambilan darah tikus dilakukan melalui plexus retro orbitalis sebanyak $\pm 2.5 \mathrm{cc}$, selanjutnya darah tikus disentrifuge untuk mendapatkan serumnya. Pengukuran kadar serum kolesterol total ditentukan menggunakan metode CHOD-PAP di LPPT Universitas Gajah Mada, Yogyakarta.

Bahan-bahan yang digunakan dalam pembuatan yoghurt sinbiotik tanpa lemak dengan penambahan tepung gembili adalah susu skim/tanpa lemak segar, susu bubuk skim, inokulum Lactobacillus bulgaricus dan Streptococcus thermophilus diperoleh dari Laboratorium Bioteknologi, Fakultas Teknologi Pertanian, Universitas Gadjah Mada, Yogyakarta dan 270 gram tepung gembili yang dibuat di Poltekes Gizi Semarang. Tepung gembili dibuat dari umbi gembili (Dioscorea esculenta), pembuatan tepung dengan cara mengukus umbi gembili sampai matang setelah itu dipotong kecil - kecil, pengeringan menggunakan sinar matahari, dihaluskan, dan diayak melewati ayakan 80 mesh. Proses pembuatan yoghurt sinbiotik tanpa lemak dengan penambahan tepung gembili dilakukan di Poltekes Gizi Semarang.

Data yang berdistribusi normal diuji dengan one way ANOVA dan paired t test dan data yang berdistribusi tidak normal diuji dengan Kruskal Wallis dan Wilcoxon. ${ }^{12}$

\section{HASIL}

Perkembangan Berat Badan dan Asupan Pakan Standar Tikus Wistar

\section{Asupan Pakan}

Setiap hari subjek mendapatkan pakan standar sebanyak 20 gram, asupan pakan subjek dapat dilihat dari selisih 
pemberian pakan standar dengan sisa pakan yang ada. Sisa pakan ditimbang setiap hari selama penelitian berlangsung.

Tabel 1. Hasil Analisis Asupan Pakan Tikus

\begin{tabular}{lcccccc}
\hline Kelompok & $\mathbf{n}$ & $\begin{array}{c}\text { Aklimatisasi } \\
\text { Rerata } \pm \text { SD }\end{array}$ & $\begin{array}{c}\text { Hiperkoles } \\
\text { Rerata } \pm \text { SD }\end{array}$ & $\begin{array}{c}\text { Intervensi } \\
\text { Rerata } \pm \text { SD }\end{array}$ & $\begin{array}{c}\text { Hiperkol } \\
\text { es- } \\
\text { Interven } \\
\text { si }\end{array}$ & $\begin{array}{c}\mathbf{p} \\
\text { Kruskal } \\
\text { Walis }\end{array}$ \\
\hline K & 6 & $19.48 \pm 0.71$ & $19.62 \pm 0.49$ & $19.68 \pm 0.20$ & 0.917 & 0.253 \\
P1 & 6 & $19.95 \pm 0.12$ & $19.95 \pm 0.06$ & $19.82 \pm 0.28$ & 0.109 & \\
P2 & 6 & $19.86 \pm 0.28$ & $19.58 \pm 0.45$ & $19.71 \pm 0.35$ & 0.394 & \\
P3 & 6 & $19.60 \pm 0.64$ & $19.89 \pm 0.21$ & $19.63 \pm 0.28$ & 0.138 & \\
\hline
\end{tabular}

Tabel 1 menunjukkan bahwa terjadi penurunan dan kenaikan asupan pakan standar tikus, namun secara statistik penurunan dan kenaikan tersebut tidak signifikan. Hasil penelitian menunjukkan perbandingan kelompok- kelompok sebelum dan setelah pemberian pakan intervensi tidak ada beda.
2. Berat Badan

Penimbangan berat badan tikus dilakukan tiga hari sekali oleh peneliti. Selama penelitian berlangsung telah dilakukan penimbangan berat badan tikus sebanyak 12 kali dimana tiga kali penimbangan berat badan dilakukan saat tahap aklimatisasi, lima kali penimbangan saat tahap pemberian pakan tinggi kolesterol, dan empat kali penimbangan saat tahap intervensi.

Tabel 2. Hasil Analisis Berat Badan Tikus

\begin{tabular}{lcccccc}
\hline Kelompok & n & $\begin{array}{c}\text { Aklimatisasi } \\
\text { Rerata } \pm \text { SD }\end{array}$ & $\begin{array}{l}\text { Hiperkoles } \\
\text { Rerata } \pm \text { SD }\end{array}$ & $\begin{array}{c}\text { Intervensi } \\
\text { Rerata } \pm \text { SD }\end{array}$ & $\begin{array}{c}\text { P } \\
\text { Hiperkol } \\
\text { es- } \\
\text { Interven } \\
\text { si }\end{array}$ & $\begin{array}{c}\text { p } \\
\text { Kruskal } \\
\text { Walis }\end{array}$ \\
\hline K & 6 & $155.7 \pm 25.99$ & $211.5 \pm 25.62$ & $230.5 \pm 29.0$ & 0.002 & 0.079 \\
P1 & 6 & $155.8 \pm 7.07$ & $219.2 \pm 14.77$ & $241.7 \pm 26.64$ & 0.020 & \\
P2 & 6 & $161.5 \pm 16.84$ & $211.0 \pm 21.15$ & $224.5 \pm 23.57$ & 0.027 & \\
P3 & 6 & $152.2 \pm 3.12$ & $212.8 \pm 11.65$ & $241.8 \pm 9.17$ & 0.000 & \\
\hline
\end{tabular}

Tabel 2 menunjukkan bahwa pada semua kelompok terjadi peningkatan berat badan yang bermakna $(\mathrm{p}<0.05)$. Pada hasil analisis dengan uji Kruskal Walis menunjukkan tidak ada beda peningkatan berat badan antara masing - masing kelompok ( $p>0.05$ ).

\section{Kolesterol Total}

Pengambilan darah dilakukan pada semua kelompok perlakuan setelah tahap aklimatisasi, tahap pemberian pakan tinggi kolesterol, dan tahap intervensi.

Tabel 3. Rata- Rata Kadar Kolesterol Total Sebelum dan Sesudah Pemberian Pakan Tinggi Kolesterol

\begin{tabular}{lccccccc}
\hline $\begin{array}{c}\text { Kolesterol } \\
\text { Total }\end{array}$ & n & $\begin{array}{c}\text { Sebelum } \\
(\mathbf{m g} / \mathbf{d l})\end{array}$ & $\begin{array}{c}\text { Sesudah } \\
(\mathbf{m g} / \mathbf{d l})\end{array}$ & $\mathbf{p}$ & $\begin{array}{c}\text { Peningkatan } \\
(\mathbf{m g} / \mathbf{d l})\end{array}$ & $\begin{array}{c}\text { Persen } \\
\text { Peningkatan } \\
(\mathbf{\%})\end{array}$ & $\begin{array}{c}\mathbf{p} \\
\text { ANOVA }\end{array}$ \\
\hline $\mathbf{K}$ & 6 & $\begin{array}{c}73.98 \pm \\
10.19\end{array}$ & $\begin{array}{l}74.77 \pm \\
8.91\end{array}$ & .816 & $0.78 \pm 7.80$ & 1.06 & .782 \\
$\mathbf{P 1}$ & 6 & $\begin{array}{c}71.33 \pm \\
17.18\end{array}$ & $\begin{array}{c}73.80 \pm \\
14.47\end{array}$ & .710 & $2.47 \pm 15.32$ & 3.46 & \\
& & & & & & &
\end{tabular}




\begin{tabular}{|c|c|c|c|c|c|c|}
\hline $\mathbf{P 2}$ & 6 & $\begin{array}{c}55.93 \pm \\
13.30\end{array}$ & $\begin{array}{l}67.15 \pm \\
7.12\end{array}$ & .043 & $11.22 \pm 10.19$ & 20.06 \\
\hline $\mathbf{P 3}$ & 6 & $\begin{array}{l}74.60 \pm \\
20.71\end{array}$ & $\begin{array}{c}80.93 \pm \\
16.24\end{array}$ & .649 & $6.33 \pm 32.11$ & 8.48 \\
\hline
\end{tabular}

Tabel 3 menunjukkan bahwa pada semua kelompok mengalami peningkatan kadar kolesterol total, namun kenaikan kadar kolesterol total yang signifikan hanya terjadi pada kelompok P2 $(\mathrm{p}<0.05)$. Perbedaan rerata peningkatan kadar kolesterol total antar kelompok dianalisis menggunakan uji anova one-way, didapatkan hasil bahwa tidak ada perbedaan kadar kolesterol total antar kelompok ( $\mathrm{p}>0.05)$.

Tabel 4. Rata- Rata Kadar Kolesterol Total Sebelum dan Sesudah Pemberian Yoghurt Sinbiotik Tanpa Lemak dengan Penambahan Tepung Gembili

\begin{tabular}{|c|c|c|c|c|c|c|c|}
\hline $\begin{array}{c}\text { Kolesterol } \\
\text { Total }\end{array}$ & $\mathbf{n}$ & $\begin{array}{c}\text { Sebelum } \\
(\mathrm{mg} / \mathrm{dl})\end{array}$ & $\begin{array}{c}\text { Sesudah } \\
(\mathrm{mg} / \mathrm{dl})\end{array}$ & $\mathbf{p}$ & $\begin{array}{c}\text { Penurunan } \\
\text { (mg/dl) }\end{array}$ & $\begin{array}{c}\text { Persen } \\
\text { Penurunan } \\
(\%)\end{array}$ & $\stackrel{p}{\text { ANOVA }}$ \\
\hline $\mathbf{K}$ & 6 & $74.77 \pm 8,91$ & $70.08 \pm 7.29$ & .120 & $4.68 \pm 6.13$ & 6.59 & .360 \\
\hline P1 & 6 & $\begin{array}{c}73.80 \pm \\
14.47\end{array}$ & $\begin{array}{c}66.32 \pm \\
11.50\end{array}$ & .077 & $7.48 \pm 8.24$ & 11.28 & \\
\hline P2 & 6 & $67.15 \pm 7.12$ & $\begin{array}{l}59.87 \pm \\
12.62\end{array}$ & .102 & $7.28 \pm 8.92$ & 12.16 & \\
\hline P3 & 6 & $\begin{array}{c}80.93 \pm \\
16.24 \\
\end{array}$ & $\begin{array}{c}68.65 \pm \\
14.73 \\
\end{array}$ & .002 & $12.28 \pm 5.23$ & 17.89 & \\
\hline
\end{tabular}

Tabel 4 menunjukkan bahwa semua kelompok (K, P1, P2, dan P3) mengalami penurunan kadar kolesterol total, namun penurunan kadar kolesterol total secara signifikan hanya terjadi pada kelompok perlakuan P3 $(\mathrm{p}<0.05)$. Perbedaan rerata penurunan kadar kolesterol total antar kelompok dianalisis menggunakan uji anova one-way, didapatkan hasil bahwa tidak ada perbedaan kadar kolesterol total antar kelompok $(\mathrm{p}>0.05)$

\section{PEMBAHASAN}

Pada tahap aklimatisasi rerata kadar kolesterol tikus pada semua kelompok sudah mengalami hiperkolesterolemia ( $\geq 54 \mathrm{mg} / \mathrm{dL}) .{ }^{13} \mathrm{Hal}$ ini dikarenakan kemungkinan adanya tindakan yang dilakukan saat penelitian terhadap tikus seperti : pengukuran berat badan, pengandangan individu, dan pembersihkan kandang. Tindakan tersebut dapat menyebabkan tikus mengalami stres, sehingga kadar kolesterol total tikus mengalami peningkatan. ${ }^{14}$ Mekanisme stres dapat menyebabkan kolesterol total meningkat dikarenakan adanya hormon kortisol dan epinefrin. Hormon tersebut diproduksi oleh kelenjar adrenal, disekresikan sebagai respon terhadap kondisi stres. Hormon epinefrin akan meningkatkan sekresi VLDL (Very Low Density Lipoprotein dan LDL (Low Density Lipoprotein) sehingga menyebabkan hiperkolesterolemia. Dalam keadaan stres juga disekresikan hormon kortisol, dimana mengalami peningkatan mencapai 20 kali lipat. Kortisol menguraikan simpanan lemak lebih dari normal sehingga kadar kolesterol dalam darah meningkat. ${ }^{15}$ Hasil analisis data kolesterol total menunjukkan bahwa setelah diberikan pakan hiperkolesterol terjadi peningkatan kolesterol total pada semua kelompok atau hiperkolesterolemia, namun hanya pada kelompok P2 yang peningkatanya bernilai signifikan $(p<0.05)$. Mekanisme hiperkolesterolemia dimulai dari asupan lemak jenuh dan kolesterol yang berasal dari otak sapi akan dicerna di dalam usus halus sehingga menghasilkan asam lemak bebas, trigliserida, fosfolipid, dan kolesterol. Selanjutnya senyawasenyawa tersebut diubah menjadi kilomikron setelah diserap oleh usus. Terdapat sisa pemecahan kilomikron berbentuk kolesterol bebas bersama dengan apoprotein membentuk VLDL. Selanjutnya enzim lipoprotein lipase sel endotelial mengubah VLDL menjadi IDL (Intermediate Density Lipoprotein) yang bertahan selama 2-6 jam sebelum berubah menjadi LDL. Apabila kadar LDL dalam tubuh berada pada konsentrasi tinggi, kolesterol akan menempel pada dinding pembuluh darah dan menimbulkan plak. ${ }^{16}$

Pemberian yoghurt sinbiotik tanpa lemak dengan penambahan tepung gembili dapat menurunkan rasio kolesterol total pada semua kelompok (P1, P2, dan P3). Hasil analisis uji beda paired t test menunjukkan hanya pada kelompok $\mathrm{P} 3$ 
yang kadar kolesterol total menurun secara signifikan, hal ini kemungkinan dikarenakan P3 mendapat dosis tertinggi bila dibandingkan dengan kelompok perlakuan lainnya. Penurunan kolesterol total dari tertinggi sampai terendah, yaitu berturutturut kelompok P3 (17,89\%), P2 (12,16\%), dan P1 $(11,28 \%)$.

Penurunan kadar kolesterol total dipengaruhi oleh adanya inulin, bakteri asam laktat Streptococcus thermophilus dan Lactobacillus bulgaricus yang terdapat dalam yoghurt sinbiotik tanpa lemak dengan penambahan tepung gembili. Inulin diketahui dapat meningkatkan viskositas di saluran cerna dan meningkatkan ketebalan lapisan usus halus, sehingga mencegah penyerapan kolesterol dan meningkatkan ekskresinya melalui feces. Hal tersebut menyebabkan katabolisme kolesterol dan memberi efek hipokolesterolemi. ${ }^{17}$ Inulin terfermentasi di kolon oleh BAL menghasilkan asam lemak rantai pendek seperti asam butirat dan asam propionat. Asam lemak rantai pendek ini dapat mempengaruhi metabolisme kolesterol di hati. Asam propionat diidentifikasi dapat menurunkan kadar kolesterol dengan cara menghambat kerja enzim $\beta$ hydroxy- $\beta$ methyl glutamyl CoA (HMG-CoA) reductase yang berperan dalam sintesis kolesterol. Selain itu asam propionat juga dapat menghambat inkorporasi asetat menuju plasma kolesterol dengan cara asam propionat berkompetisi dengan transporter asam asetat menuju ke sel hepatosit. Hal ini akan berakibat pada menurunnya sintesis kolesterol karena asetat merupakan prekusor dalam pembentukan kolesterol. ${ }^{18,19}$

Mekanisme penurunan kolesterol oleh BAL diantaranya melalui mekanisme asimilasi kolesterol dan transformasi kolesterol menjadi koprostanol. Asimilasi kolesterol terjadi melalui mekanisme pengambilan kolesterol oleh bakteri asam laktat yang kemudian kolesterol tersebut akan berinkorporasi dengan membran sel bakteri sehingga menyebabkan kolesterol tidak dapat diabsorpsi. Bakteri asam laktat juga dapat mengubah kolesterol menjadi senyawa koprostanol, hal ini diakibatkan karena adanya enzim kolesterol redutase yang dihasilkan oleh BAL. Koprostanol tidak diabsopsi oleh usus halus, namun langsung diekskresikan bersama feces. ${ }^{4,17}$

Kelompok $\mathrm{K}$ juga mengalami penurunan kadar kolesterol total sebesar 6,59\% meskipun tidak diberikan pakan intervensi, dikarenakan pada kelompok K hanya mendapat pakan standar saja dan tidak diberikan pakan hiperkolesterol kembali. Selain itu dalam pakan standar juga terdapat serat sebesar $8 \%$, dimana dapat berpengaruh terdapat penurunan kolesterol. ${ }^{20}$

\section{SIMPULAN}

Pemberian dosis yoghurt sinbiotik tanpa lemak dengan penambahan tepung gembili dengan dosis $4 \mathrm{ml} /$ hari dalam waktu 2 minggu dapat menurunkan kadar kolesterol total darah tikus hiperkolesterolemia secara signifikan $(\mathrm{p}<0.05)$.

\section{DAFTAR PUSTAKA}

1. WHO. Cardiovascular disease. Fact sheet no. 317. WHO, Geneva, Switzerland 2009. Diunduh dari http://www.who.int/mediacentre/factsheets/fs317/e n/print.html

2. Ondrejovicova I, Muchova J, Mislanova C, Nagyova Z, Durackova Z. Hypercholesterolemia, Oxidative Stress and Gender Dependence in Children. Prague Medical Report. Vol. 111 (2010) No. 4, p. 300-312.

3. Badan Penelitian dan Pengembangan Kesehatan Departemen Kesehatan RI. Laporan hasil Riset Kesehatan Dasar 2013. Jakarta; 2013.

4. Baroutkoub A, Mehdi RZ, Beglarian R, Hassan J, Zahra S, Mohammad MS, et al. Effects of probiotic yoghurt consumption on the serum cholesterol levels in hypercholestromic cases in Shiraz Southern Iran. Scientific Research and Essays Vol. 5(16), pp. 2206-2209, 18 August, 2010.

5. Krummel DA. Medical nutrition therapy in cardiovascular disease. In: Mahan LK, EscottStump S, editors. Krause's food, nutrition and diet therapy 12th ed. Philadelphia: Elsevier; 2013.

6. Anandharaj M, Sivasankari B, dan Rani RP. Effects of Probiotics, Prebiotics, and Synbiotics on Hypercholesterolemia: A Review. Chinese Journal of Biology Volume 2014, Article ID 572754, 7 pages.

7. Jenie BSLS, Saputra YM, dan Widaningrum. Sensory Evaluation and Survival of Probiotics in Modified Banana Flour Yoghurt during Storage. J. Teknol. Dan Industri Pangan. Vol. 24 No. 1 Th. 2013.

8. Nair KK, Kharb S, Thompkinson DK. Inulin dietary fiber with functional and health attributes-A review. Food Reviews International, 26:189-203, 2010.

9. Onge MP, Edward RF, Jones PJH. Consumption of fermented and non fermented dairy products: effects on cholesterol concentrations and metabolism. Am J Clin Nutr 2000;71:674-81.

10. Winarti S, Harmayani E, dan Nurismanto R. Characteristic and inulin profil of wild yam (Dioscorea spp.). Agritech., 2011; Vol. 31, No. 4.

11. World Health Organization (WHO). General Guidelines for Metodologies on search and Evaluation of Traditional Medicine. Geneva : WHO, 2001

12. Soekidjo N. Metodologi Penelitian Kesehatan. Jakarta : Rineka Cipta. 2012 
13. Harini M, Astirin PO. Blood Cholesterol Level of Hypercgolesterolemia Rat (Rattus norvegicus) After VCO Treatment. Journal Bioscience Vol 1 No $2: 53-58,2009$.

14. Balcombe JP, Bernard ND, Sandusky C. Laboratory Rountines Cause Animal Stress. American Association for Laboratory Animal Science;2004: $43 ; 6$

15. Alwiyah S. Perbedaan kadar low density lipoprotein (LDL) darah tikus wistar (Rattus norvegicus) jantan setelah dipapar stressor rasa sakit renjatan listrik [skripsi]. Program Studi Kedokteran Gigi. Universitas Jember ; 2012.

16. Brata HW. Hubungan Pola Makan, Obesitas, Keteraturan Berolahraga dan Kebiasaan Merokok dengan kejadian Hiperkolesterolemia [skripsi]. Semarang: Universitas Muhammadiyah Semarang. 2009.

17. Lay GO dan Min TL. Cholesterol-Lowering Effects of Probiotics and Prebiotics: A Review of in Vivo and in Vitro Findings. Int. J. Mol. Sci. 2010, 11, 2499-2522.

18. Beylot M. Effects of inulin-type fructans on lipid metabolism in man and in animal models. British Journal of Nutrition. 2005, 93, Suppl. 1, S163S168.

19. Kaur N,Gupta AK. Applications of inulin and oligofructose in health and nutrition. J. Biosci 2002. Vol. 27 No. 7.

20. Anderson JW, Deakins DA, Bridges SR. Soluble Fiber : Hypocholesterolemic Effects and Proposepd Mechanisms. In : Kritchevsky D, Bonfield C, Anderson JW, editor. Dietary Fiber ; Chemistry, Physiology, and Health Effects. New York : Plenum Press ; 1990. P. 339 - 63. 